\title{
SUMBANGAN ADMINISTRASI KEARSIPAN TERHADAP PIMPINAN ORGANISASI DALAM PENGAMBILAN KEPUTUSAN
}

\author{
Oleh : Sudaryanto \\ sudaryanto@uny.ac.id
}

\section{Abstrak}

Kenyataan menunjukkan bahwa setiap pimpinan organisasi, baik tingkat puncak, menengah, maupun bawah tidak dapat lepas dari kegiatan pengambilan keputusan dalam kerangka pencapaian tujuan. Optimalisasi kuantitas, kualitas, kecepatan, dan ketepatan pengambilan keputusan dapat dipenganuhi oleh beberapa faktor, misalnya kemampuan pimpinan, tujuan yang ingin dicapai, dan tersedianya informasi. Salah satu faktor penting dalam pembahasan ini ialah faktor tersedianya informasi. Dengan demikian ketersediaan informasi menjadi sumber bahan dan pertimbangan dalam proses pengambilan keputusan. Perlu disadari bahwa setiap organisasi sebenamya telah memiliki salah satu sumber informasi yang dapat dimanfaatkan untuk keperluan pengambilan keputusan, yaitu dari arsip atau warkat-warkat yang dimilikinya. Oleh karena itu pengelolaan arsip atau warkatwarkat hendaknya dapat dilakukan dengan sebaik-baiknya agar informasi yang diperlukan dapat disediakan secara lengkap, akurat, dan cepat. Jika demikian administrasi kearsipan dalam suatu organisasi dapat memberikan sumbangan yang maksimal kepada pimpinan dalam rangka pengambilan keputusan.

\section{Pendahuluan}

Salah satu tugas penting da-ri pimpinan suatu organisasi secara institusional adalah mengambil keputusan-keputusan dalam rangkaian usaha pencapaian tujuan yang telah ditentukan. Kecepatan dan ketepatan mengambil keputusan-keputusan tersebut sangat diperlukan dan sangat penting artinya demi kelancaran serta keberhasilan pencapaian tujuan. Akan tetapi mengambil keputusan. secara cepat dan tepat tidaklah mudah. Pimpinan organisasi tentu memerlukan adanya bahanbahan keterangan atau informasi untuk kepentingan pengambilan keputusan tersebut di samping faktor kemampuan dan kecakapan yang harus dimiliki oleh pimpinan organisasi itu sendin. 
Sesuai dengan judul di atas, tulisan ini tidak membahas ataupun menguraikan secara lengkap dan rinci semua faktor yang dapat mempengaruhi atau menentukan keberhasilan pimpinan organisasi dalam rangka mengambil keputusan-keputusan. Penulis dalam kesempatan ini ingin mencoba menguraikan salah satu di antara faktor-faktor di atas, yaitu sejauh manakah sumbangan administrasi kearsipan terhadap pimpinan organisasi dalam rangka mengambil keputusan.

\section{Adminstrasi Kearsipan}

Menurut The Liang Gie, yang dimaksud dengan administrasi kearsipan adalah: segenap proses penyelenggaraan dalam suatu usaha kerja sama yang berkenaan dengan penyimpanan warkat secara tertib untuk keperluan pengingatan organisasi yang bersangkutan. (1977: 294). Sedangkan Subroto berpendapat bahwa yang dimaksud dengan administrasi kearsipan adalah; aktivitas penerimaan, pencatatan, penyimpanan, penggunaan, pemeliharaan, penyusutan dan pemusnahan arsip-arsip.(1977:2)

Dari kedua pendapat di atas dapat diketahui bahwa masingmasing mempunyai latar belakang dan sudut pandang yang berbeda. Pandapat pertama memandang bahwa inti daripada administrasi keripan adalah pada kegiatan penyimanan warkat. Sedangkan pendapat yang kedua memandang bahwa administrasi kearsipan itu dilihat dari segi proses kegiatannya secara terinci terhadap pengurusan arsip mulai dari saat penerimaannya sampai dengan pemusnahannya. Namun demikian jika diperhatikan kedua pendapat di atas mempunyai prinsip yang sama, demikian pula cbyek atau sasarannya yaitu aktivitas yang berkenaan dengan penanganan atau pengurusan terhadap arsip.

Dari uraian di atas kedua pendapat tersebut dapat dibenarkan, artinya untuk dapat melakukan peyimpanan arsip atau warkat secara tertib memang diperlukan adanya aktivitas-aktivitas lain seperti aktivias penerimaan, pencatatan, penyimpanan, pemeliharaan, penyusutan dan pemusnahan.

Kiranya dapat disimpulkan bahwa yang dimaksud dengan administrasi kearsipan adalah rangkaian kegiatan dalam suatu usaha kerja sama yang meliputi penerimaan, pencatatan, penyimparan, pemeliharaan, penggunaan, penyusutan dan pemusnahan warkat secara tertib dan teratur.

Fungsi dan Peranan Administrasi Kearsipan:

a. Fungsi Administrasi Kearsipan

Menurut Sutarto, yang dimaksud dengan fungsi adalah sekelompok aktivitas yang tergolong pada jenis yang sama berdasarkan sifat-sifat ataupun pelaksanaannya 
(1981:135). Secara sederhana batasan di atas dapat diperjelas pengertiannya bahwa kegiatan-kegiatan yang sejenis karena sifat maupun pelaksanaannya digabungkan menjadi suatu kesatuan aktivitas tertentu. Dengan demikian sesuai dengan pengertian administrasi kearsipan, fungsi administrasi kearsipan adalah merupakan suatu satuan atau unit aktivitas yang menyelenggarakan rangkaian aktivitas penerimaan, pencatatan, penyimpanan, penggunaan, pemeliharaan, penyusutan, dan pemusnahan warkat secara teratur dalam suatu organisasi.

b. Peranan Administrasi Kearsipan

Untuk mengetahui sejauh manakah peranan administrasi kearsipan, tentu tidak bisa teriepas dari peranan arsipnya itu sendiri. Oleh karena itu beberapa hal yang berkenaan dengan arsip terlebih dahulu perlu diketahui:

1) Pengertian Arsip

Dari banyak ahli yang telah memberikan batasan dan pengertian tentang arsip, pada hakikatnya dapat diambil suatu kesimpulan bahwa yang dimaksud arsip adalah kumpulan warkat yang disimpan secara teratur dan sistematis pada suatu tempat tertentu, agar jika diperlukan dapat diketemukan kembali dengan cepat dan tepat. Dari batasan di atas terkandung beberapa pengertian yang dapat diuraikan lebin lanjut secara jelas dan terperinci.
Pertama, bahwa seperti telah diuraikan di depan arsip adalah merupakan kumpulan dari warkatwarkat. Kedua, bahwa warkat-warkat tersebut disimpan secara teratur dan sistematis artinya warkat-warkat tersebut pengurusan yang pada intinya pada penyimpanan dilakukan dan dilaksanakan dengan menggunakan aturan-aturan tertentu secara logis. Ketiga, bahwa warkat-warkat tersebut hanus disimpan pada suatu tempat tertentu, artinya penyimpanan warkat-warkat tersebut ditempatkan pada suatu tempat yang pasti atau khusus dan tidak terganggu maupun mengganggu penyimpanan bahkan aktivitas lainnya. Keempat, dari batasan itu pula dijumpai dua istilah yang dalam penggunaan nya sehari-hari baik di lingkungan instansi pemerintah maupun swasta silih berganti. Istilah dimaksud adalah "warkat" dan arsip. Apakah sebenamya warkat itu? Kemajuan ilmu pengetahuan dan teknologi dewasa ini ternyata membawa pengaruh pula terhadap batasan maupun pengertian warkat.

Menurut The Liang Gie, warkat adalah setiap catatan tertulis atau bergambar yang memuat keterangan mengenai sesuatu hal atau peristiwa yang dibuat orang untuk membantu ingatannya (1978:211). Pendapat ini tidak salah, karena hal itu telah dirumuskan sesuai dengan perkembangan yang ada, khususnya di bidang kewar- 
katan. Namun dewasa ini bukan mustahil bahwasanya dengan adanya kemajuan ilmu pengetahuan dan teknologi, pengertian warkat menjadi berkembang seperti apa yang dikemukakan oleh Sutarto bahwa warkat adalah segala sesuatu baik yang tertulis maupun yang dapat dilihat dan didengar seperti hasithasil rekaman, film, dan sebagainya (1981: 169).

Secara lengkap dapat disimpulkan bahwa warkat adalah setiap catatan baik tertulis, tergambar, maupun terekam yang sengaja Chyat orang untuk membantu ingatan. Jadi jelaslah kiranya kalau di atas disebutkan bahwa arsip itu adalah kumpulan warkat, maka warkat adalah merupakan bendabenda arsip.

2) Kegunaan Arsip

Uraian di atas telah disinggung bahwa salah satu tujuan dari kegiatan penyimpanan arsip atau warkat-warkat ialah agar apabila dibutuhkan kembali dapat diketemukan dengan cepat dan tepat. Dari pernyataan tersebut terkandung pengertian bahwa dipentukannya kembali sesuatu warkat tentu karena memiliki kegunaan tertentu. $\mathrm{Hal}$ ini kiranya dapat dimengerti, mengingat somakin luasnya pengertian maupun perumjudan daripada warkat itu sendiri. Untuk jelasnya mengenai macam-macam kegunaan arsip atau warkat-warkat dapat diikuti melalui uraian berikut ini.
Alasan mengapa arsip atau warkat-warkat itu perlu disimpan, ialah karena memiliki nilai-nilai kegunaan sebagai berikut:

a. Nilai administrasi

b. Nilai hukum

c. Nilai keuangan

d. Nilai penelitian

e. Nilai pendidikan

f. Nilai dokumentasi

g. Nilai haluan organisasi

h. Nilai pelaksanaan organisasi

i. Nilai sejarah

Di samping adanya nilai-nilai kegunaan di atas, mengapa warkatwarkat itu disimpan? Menurut Miftah Thoha, bahwa arsip itu perlu disimpan, karena warkat-warkat itu digolong-golongkan sesuai arti pentingnya bagi kehidupan suatu organisasi, yaitu :

a. Golongan warkat atau arsip vital

b. Golongan warkat atau arsip penting

c. Golongan warkat atau arsip biasa

d. Golongan warkat atau arsip tidak penting (1977:49).

Jadi pertanyaannya adalah, mengapa warkat-warkat atau arsip itu perlu disimpan. Sebab warkatwarkat atau arsip itu mempunyai nilai kegunaan dan arti penting bagi kehidupan suatu organisasi.

3). Peranan Arsip

Dari uraian di atas dapat diketahui bahwa warkat-warkat atau arsip yang disimpan oleh suatu organisasi mempunyai bermacam- 
macam nilai kegunaan dan arti penting. Dengan demikian berbagai macam keterangan atau informasi akan diperoleh dari tempat penyimpanan arsip itu, apabila memerlukannya.

Jika demikian hainya dapat dimengerti bahwa peranan arsip adalah merupakan salah satu tempat sebagai sumber keterangan atau sumber informasi. Hal itu kiranya sesuai apa yang dikemukakan oleh Subroto, bahwa peranan arsip ialah sebagai sumber informasi dan sumber dokumen. (1979:22).

Selanjutnya agar peranan arsip tersebut benar-benar dapat berfungsi sebagai sumber informasi dalam suatu organisasi, maka arsip atau warkat tersebut pertu diatur dengan sebaik-baiknya agar dapat lebih berdayaguna dan membantu kelancaran aktivitas organisasinya. Siapakah yang harus melaksanakan fungsi tersebut, tidak lain adalah suatu satuan tertentu dalam organisasi yang secara khusus ditugasi menangani dan mengeiola warkat-warkat tersebut. Tepatnya adalah suatu satuan yang disebut satuan kerja administrasi kearsipan. Jadi peranan administrasi kearsipan adalah sebagai salah satu satuan aktivitas yang melayani keterangan-keterangan atau informasi yang diperlukan untuk kepentingan organisasi.
Hubungan Administrasi Kearsipan Dengan Aktivitas Pimpinan Orgaisasi Dalam Rangka Mengambll Keputusan

Keputusan-keputusan yang diambil oleh pimpinan suatu organisasi tentu saja bukan sekedar sesuatu yang terjadi secara kebetulan. Apalagi keputusan-keputusan itu bersifat institusional, dan bukan merupakan keputusan seseorang atau atas nama pribadi. Keputusan yang diambil harus didasarkan atas kepentingan bersama, dan bukan kepentingan pribadi pula. Oleh karena itu pengambilan keputusan harus didasarkan atas pertimbanganpertimbangan yang matang dan pilihan dari altematif secara cemat dan tepat.

Hal tersebut sesuai dengan pendapat bahwa, hakikat pengambilan keputusan adalah: suatu pendekatan yang sistematis terhadap hakikat suatu masalah, pengumpulan fakta-fakta dan data, penentuan yang matang dari altematif yang dihadapi dan mengambi tindakan yang menurut perhitungan merupakan tindakan yang paling tepat (Sondang SP., 1982 : 83). Lebih lanjut dinyatakan bahwa pengambilan keputusan tidak dapat dilakukan secara "sembrono" karena cara pendekatan kepada pengambilan keputusan harus didasarkan kepada sistematika tertentu. Dari pemyataan tersebut di atas menunjukkan bahwa betapa pen- 
tingnya arti keputusan yang akan diambil untuk kepentingan organisasi itu, sehingga pengambilan keputusan harus dilakukan dengan hati-hati dan harus melalui langkah atau presedur iertentu.

Yang dimaksud dengan sistematika ialah unsur-unsur atau faktorfaktor yang menentukan keberhasilan dalam proses pengambilan keputusan. Dijelaskan bahwa yang dimaksud dengan sistematika tertentu itu adalah sebagai berikut.

a. Kemampuan organisasi, dalam arti tersedianya sumber-sumber yang nantinya akan digunakan untuk melaksanakan keputusan yang diambil

b. Tenaga yang tersedia serta kualifikasinya

c. Filsafat yang dianut oleh organisasi

d. Situasi lingkungan intem dan ekstem yang akan mempengaruhi jalannya roda administrasi dan manajemen di dalam organisasi

Dari penjelasan atau pendapat di atas ternyata banyak faktor ataupun unsur yang sangat diperlukan di dalam rangka proses peengambilan keputusan. Pertama, tersedianya informasi yang lengkap, tepat dan cepat. Kedua, diperlukan adanya tenaga yang berkemampuan, termasuk kemampuan pimpinan dari organisasi untuk mengambil keputusan. Ketiga, dapat dilihat bahwa bagaimanapun juga keputus- an yang diambil secara institusional hanus mendasarkan pula kepada haluan dan tujuan organisasi. Sedangkan faktor yang terakhir bahwa perubahan atau perkembangan yang terjadi baik di lingkungan sendiri maupun situasi di luar organisasi dapat mempengaruhi bahkan diperlukan sebagai bahan masukan untuk kepentingan pengambilan keputusan itu.

Berdasarkan pengamatan terhadap faktor atau unsur-unsur tersebut, dapat digarisbawahi bahwa antara faktor atau unsur yang satu dengan lainnya saling mendukung di dalam rangka mencapai kecepatan dan ketepatan proses pengambilan keputusan.

Menyadari akan pentingnya faktor-faktor tersebut, aktivitas penyediaan keterangan atau informasi memang bukan merupakan faktor yang paling menentukan keberhasilan proses pengambilan keputusan. Namun andil atau sumbangan dari aktivitas pelayanan dan penyediaan keterangan yang dalam uraian terdahulu dilaksanakan oleh satuan kerja administrasi kearsipan tidak dapat diabaikan. Dengan administrasi kearsipan, melalui pengelolaan warkat-warkat yang memiliki bermacam-macam nilai kegunaan dan arti penting bagi organisasi dengan sebaik-baiknya akan membantu pimpinan dalam rangka mengambil keputusan. 
Jadi jelaslah bahwa antara administrasi kearsipan dan aktivitas pimpinan dalam rangka mengambil keputusan mempunyai hubungan yang erat. Di satu pihak di dalam rangka proses pengambilan keputusan, pimpinan organisasi memerlukan adanya informasi secara cepat dan tepat yang salah satunya bersumber dari warkat-warkat atau arsip. Sedang di lain pihak, yaitu administrasi kearsipan yang fungsi pokoknya berintikan pada penyimpanan warkat-warkat memang dimaksudkan sebagai sumber informasi dan sumber ingatan bagi kepentingan organisasi di dalam proses aktivitasnya mengambil keputusan.

Kesimpulan di atas kiranya sesuai dengan pernyataan atau pendapat-pendapat berikut, yaitu: Sesungguhnya pentingnya informasi bagi pimpinan organisasi bukanlah merupakan hal yang baru. Sejak adanya manusia yang hidup berorganisasi, sejak saat itu pulalah informasi telah selalu diperlukan oleh pimpinan organisasi untuk membantunya melakukan tugas-tugasnya selaku pimpinan organisasi. Yang baru aalah peningkatan kesadaran tentang pentingnya peranan informasi bagi pimpinan untuk mengambil keputusan (Sondang SP., $1982: 83$ ).

Demikian pula seperti apa yang dikemukakan oleh Subroto, bahwa: Sebagai sumber informasi, maka arsip dapat digunakan oleh pimpinan organisasi untuk membuat keputusan secara tepat mengenal persoalan yang dihadapi, karena dokumen dapat digunakan untuk pembuktian yang sah $(1979: 8)$.

\section{Penutup}

a. Kesimpulan

Dari uraian di atas dapat ditarik beberapa kesimpulan sebagai berikut.

1. Arsip atau warkat-warkat yang dimiliki oleh suatu organisasi dapat mempunyai nilai-nilai kegunaan dan arti penting tertentu.

2. Berdasarkan alasan dan pengertian di atas, maka warkat-warkat atau arsip tersebut dapat menjadi dan dijadikan sumber informasi dan sumber ingatan bagi organisasi yang memilikinya.

3. Di samping tugas-tugas lainnya, salah satu tugas penting pula bagi pimpinan suatu organisasi yaitu dalam rangka mengambil keputusan-keputusan, sangat memerlukan adanya keterangan atau informasi secara cepat dan tepat.

4. Satuan atau unit karja administrasi kearsipan sebagai salah satu satuan dalam organisasi yang berfungsi mengelola warkatwarkat, mempunyai peranan penting sobagai satuan yang melayani penyediaan keteranganketerangan atau informasi yang diperlukan secara cepat dan tepat 
termasuk kepentingan pimpinan organisasi dalam rangka proses pengambilan keputusan.

Jedi dapat ditegaskan bahwa skikitas administrasi kearsipan daiam suatu organisasi dapat membantu pimpinan dalam proses pengambilan keputusan.

b. Rekomendasi

1. Mengingat pentingnya warkatwarkat tersebut sebagai salah satu sumber informasi dalam suatu organisasi dan begitu pesatma laju perkembangan ilmu pengetahuan dan teknologi, maka percepatan penerapan teknologi dalam bidang administrasi kearsipan sangat diperiukan. Dengan demikian dapat diberikan rekomendasi bahwa peranan administrasi kearsipan dapat memiliki kadar sumbangan atau bantuan yang semakin tinggi dalam rangka membantu kelancaran baik aktivitas organisasi secara keselunhan maupun terhadap pimpinan organisasi di dalam rangka melaksanakan tugas mengambil keputusan-keputusan untuk kepentingan organisasinya.

2. Kepada pimpinan organisasi kiramya periu semakin meningkatkan pemberdayaan kerja administrasi kearsipan untuk keperluan pengambilan keputusan.

3. Pemberdayaan kerja administrasi kearsipan, pimpinan organisasi dapat mengupayakan melalui : a) Pengembangan sistem kearsipan yang tepat

b) Penyediaan fasilitas pongelolaan arsip yang memadai

c) Pemberdayaan sumber daya manusia

\section{Daftar Pustaka}

Miftah Thoha. 1977. Pokok-pokok Pemikiran Tentang Pembakuan Tata Usaha. Yogyakarta : BPA - UGM

Sondang SP. 1982. Sistem Informasi Untuk Pengambilan Keputusan. Jakarta : PT Gunung Agung

Subroto R. 1977. Pengertian Kearsipan. Yogyakarta : BPA UGM

-1. 1979. Administrasi Perkantoran.

Yogyakarta : Fakultas Sosial dan Politik - UGM

Sutarto. 1981. Sekretaris dan Tata Warkat. Yogyakarta : Gadjah Mada University Press.

The Liang Gie, dkk. 1977. Ensiklopedi Administrasi. Jakarta : PT Gunung Agung

The Liang Gie. 1978. Administrasi Perkantoran Modem. Yogyakarta : Nur Cahaya

\section{Blodata Penulis}

Drs. Sudaryanto, adalah staf pengajar pada Program Studi Pendidikan Administrasi Perkantoran Fakultas IImu Sosial Universitas Negeri Yogyakarta. 